\title{
Te is lehetsz büvész! \\ Fedezzük fel a bűvészmutatványok matematikai titkait!
}

\section{Pintér Klára}

SZTE JGYPK TÓKI Matematika Szakcsoport

\begin{abstract}
Miközben sokan negatív emlékeket őriznek a matematika tanulásáról, lelkesen próbálják kitalálni büvészmutatványok titkait, szívesen játszanak gondolkodást igénylő játékokat, és nem gondolják, hogy ezek alapja gyakran a matematika. Ha sikerül a játékokat, trükköket beépíteni a matematika tananyagba, változhat a tanulók hozzáállása a matematikához és aktívabban vehetnek részt a tanulási folyamatban, ami hatékonyabb ismeretszerzést, képességfejlesztést eredményezhet. A matematika ilyen csábító köntösbe való felöltöztetését szimbolizálja az a papírból hajtogatott kocka, amelyet néhány mozdulattal rózsává alakithatunk¹.
\end{abstract}

Kulcsszavak: büvészmutatvnyok, kártyatrükkök, algebra, számrendszerek, térszemlélet

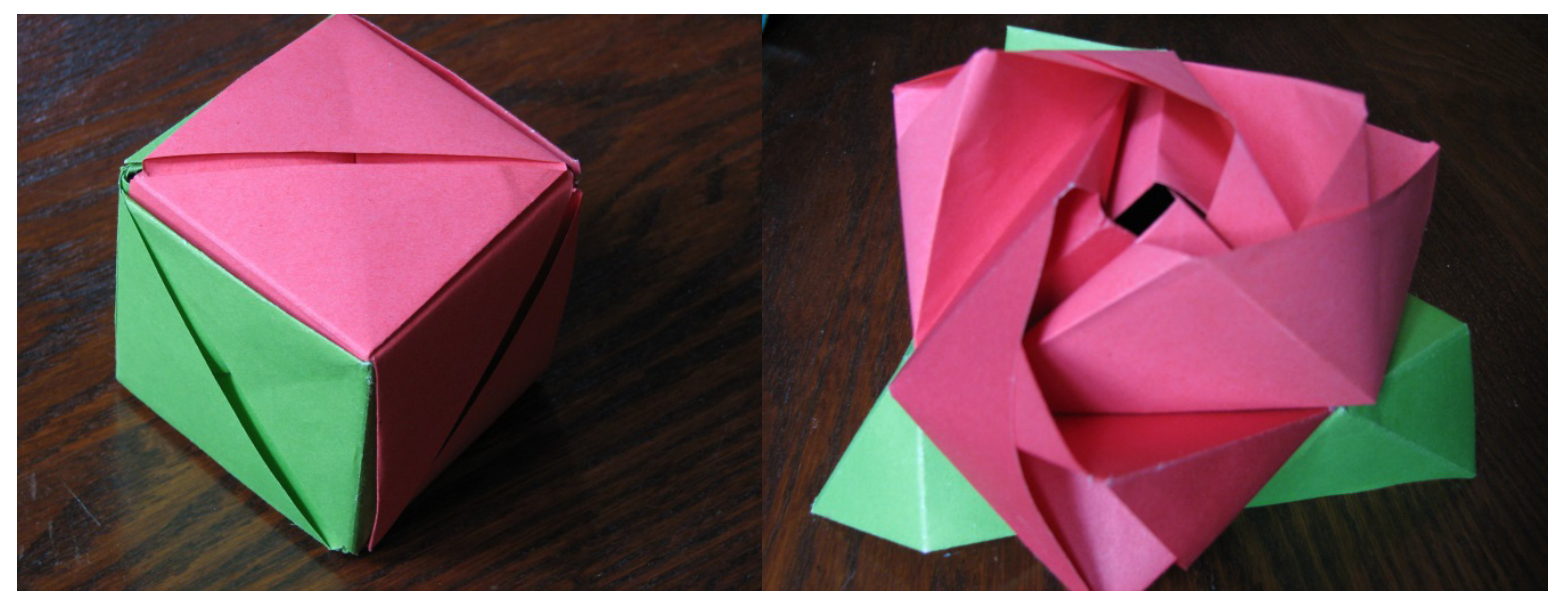

1. ábra: A bűvésztrükkök alkalmazásának módszere

A trükkök bemutatásakor a pedagógus a bűvész. A mutatvány többszöri ismétlése közben a közönség megpróbálja utánozni a bűvészt, kitalálni a trükköt. Fontos, hogy se a bűvész ne árulja el a titkát, se az ne tegye közzé a gondolatait, aki sejti a trükk nyitját. Úgy ellenőrizheti sejtésének helyességét, hogy vállalja a büvész szerepét. Így a sok kísérlet eredményeként minden tanulónak van esélye megtalálni a magyarázatot, illevte a tanulók maguk dönthetnek az esetleges tévutak feladásáról. Végül összegezzük a mutatvány lényegét, magyarázatát, matematikai hátterét. Így a problémák feldolgozásának módja nagyban segíti a problémamegoldó képesség, az induktív gondolkodás fejlődését, hiszen a motiváló problémafelvetés után a kísérletezések eredményeként a diákok sejtéseket fogalmaznak meg, azokat ellenőrzik és indokolják, gyakorolják a döntést, hogy egy ötlet mellett meddig érdemes kitartani, mikor célszerủ új gondolatot keresni. Ebben a folyamatban a pedagógus szerepe a problémafelvetés, a felfedezés lehetőségének biztosítása, és nem az ismeretközlés a megoldások helyességének

\footnotetext{
1 Vann, Valerie Origami magic rose cube
} 
kinyilatkoztatása. A diákok pedig megtapasztalják a felfedezés örömét, és szívesen gondolkodnak a matematikai problémákon. A továbbiakban a matematika különböző területeihez kapcsolódó büvészmutatványokat mutatok be, amelyek az általános iskolai matematika órákon is bemutathatók.

\section{Büvésztrükkök}

\section{Trükkök számítógépen}

A bűvészmutatványok egy része az irányított figyelemre épül. $A$ körülmények véletlenszerü változtatását a számítógépes szoftver biztosítja elfedve a trükk lényegét. Ezek megfejtése fejleszti a tanulók megfigyelőképességét, szélesíti látókörüket.

\subsection{Három kártya trükk}

A trükk:

A képernyőn megjelenik hat kártya, és a közönségnek választani kell egy lapot, és erősen gondolni kell erre a lapra. A lapok eltünnek, és amikor újra megjelennek, nem lesz köztük az a lap, amelyikre a közönség gondolt (urbanlegends.about.com/library/ bl_card_trick1.htm).

\section{A titok:}

Kezdetben teljesen misztikusnak tünik, honnan tudhatta a gép, hogy mire gondoltunk. A trükk többszöri ismétlésekor jobban megfigyeljük a körülményeket. A mutatott hat lap közül három piros, három fekete, két jumbó $(\mathrm{J})$, két dáma $(\mathrm{Q})$ és két király $(\mathrm{K})$, mindegyikből egy piros, egy fekete. Az egy lap eltüntetése után mutatott öt lap között ugyanilyen figurás lapok vannak, mindegyikböl legfeljebb egy piros, egy fekete, csak éppen a másik piros és a másik fekete, vagyis egyetlen olyan lapot sem mutat a gép másodszorra, mint amit először mutatott, így nem csoda, hogy nem lesz a képernyőn az a lap, amire gondoltunk. A lapok szélesebb körü megfigyelése teszi lehetővé a trükk megfejtését. A számítógép azért hasznos, mert minden játék alkalmával más lapokat dob fel a gép, és könnyen el tudja tüntetni az először mutatott lapokat, hogy újakat mutasson. Ezt kézben levő lapokkal jóval nehezebb megvalósítani.

\subsection{Varázsgömb}

A trükk:

A mutatvány széles körben ismert, a megoldása már kevésbé. A közönség gondol egy kétjegyű számra. Kivonja belöle a számjegyek összegét. A különbséget megkeresi a számítógép által mutatott táblázatban, ahol 1-től 99-ig minden számhoz tartozik egy jel, ami sokszor elég kacifántos. Ezt a jelet kell megjegyezni, erősen gondolni rá, és amikor rákattintunk a varázsgömbre, csodák csodája éppen ez a jel fog megjelenni (Naughton, é.n.).

A titok:

A táblázatot alaposan megfigyelve észre lehet venni, hogy a 9-cel osztható számok mellett a 90 és a 99 kivételével ugyanaz a jel áll. A helyi értékes felbontás alapján már alsó tagozatos gyerekeknek is meg lehet mutatni, hogy a különbség mindig 9 többszöröse lesz. Nagyobbaknak magyarázhatjuk úgy, hogy a természetes számok 9-es osztási maradéka megegyezik számjegyeik összegének kilences osztási maradékával, így különbségük osztható lesz 9-cel. Ellenőrizzük, hogy különbségként nem kaphatunk se 99-et, se 90-et (a lehető legnagyobb különbség a 81), így mindegy me- 
lyik 9-cel osztható különbséget kaptuk, ugyanarra a jelre gondoltunk. A számítógép alkalmazása azért szerencsés, mert a trükk egymás utáni ismétlésekor más-más jelet kapunk, ugyanis a program cserélgeti a táblázatban a számokhoz tartozó jeleket ezzel elfedve a trükköt.

A trükköt némi gyakorlással számítógép nélkül is bemutathatjuk. Egy gyufaskatulyába a közönség rakjon gyufaszálakat, számolják meg, hogy hány darabot, majd ezekből a gyufaszálakból rakják ki a gyufák darabszámát úgy, hogy kitesznek annyi gyufát, amennyi a darabszám tízeseinek száma és annyit, amennyi az egyeseké. A megmaradt gyufákat a skatulyába téve átadják a bűvésznek, aki megrázogatja azt, és megmondja, hogy hány szál gyufa van benne. A gyakorlás azért szükséges, hogy meg tudjuk különböztetni a 9 , a 18 és a 27 szál gyufa hangját a rázogatás során. A trükk a megfigyelöképesség fejlesztése mellett alkalmas arra, hogy tapasztalatot szerezzenek a tanulók a 9-cel való oszthatóságról.

\section{Logika: Hummer-féle három tárgy kitaláló}

\section{A trükk:}

A bűvész kitesz három plüssállatot az asztalra az 1-gyel, 2-vel, 3-mal jelölt helyekre és hátat fordít. A közönség soraiból választott segítő felcserél két állatot, és hangosan kimondja azoknak a helyeknek a számát, amelyeken ezek az állatok álltak. Ezt folytatja, amíg akarja. Ezután gondol az egyik állatra, a másik kettőt megcseréli, de ezt a cserét nem mondja ki - ez a titkos csere. Majd tovább folytatja a cseréket, amíg akarja. Végül a büvész megfordul, köröz a varázspálcájával és rámutat a gondolt állatra (Gardner, 1956, 63. о.).

\section{A titok:}

A büvész az elején kiszemel egy állatot, megnézi melyik helyen van. Ezután ennek az állatnak a helyét követi az ujjain a bemondás alapján úgy, hogy a mutatóujj az 1-es, a középső- a 2-es, a gyűrűsujj a 3-as pozíció. Ezt folytatja akkor is, amikor a titkos csere után tovább cserélgetnek. Amikor megfordul, megnézi, hogy az általa kiszemelt állat azon a helyen van-e, ahol az ujjai szerint lennie kell. Ha ott van, akkor az azt jelenti, hogy nem vett részt a titkos cserében, vagyis ő a gondolt állat. Ha nincs ott, akkor részt vett a titkos cserében, mégpedig azzal az állattal cserélt helyet, amelyik végül azon a helyen áll, ahol a bűvész ujjai szerint az általa kiszemelt állatnak kellene állni. Így egyikük sem lehet a gondolt állat, csak a harmadik. A trükk megoldásának felfedezése nem egyszerü, de többszöri bemutatás után azért lehetséges. A gyerekek sokszor az összes állatot próbálják követni, de a titkos cserénél rendszerint megakadnak.

\section{Számrendszerek: Pakolós kitaláló}

A trükk:

A bűvész kirak sorban hat tálcát, egy kosár kupakot, és elfordul. A közönség soraiból választott segítő kiszór az első tálcára néhány kupakot és megszámolja hány darab van. Ezután mindkét kezével megfog egy-egy kupakot, az egyiket átrakja a következő tálcára, a másikat visszadobja a kosárba. Ezt folytatja, amíg lehet, majd ugyanezt sorban a többi tálcával is végrehajtja. Végül mindegyik tálcán legfeljebb egy kupak lehet. Ekkor a bűvész megfordul, köröz a varázspálcájával, és megmondja, hogy hány kupak volt eredetileg az első tálcán. 
A titok:

A segítő mindkét kezével egy-egy kupakot fog meg, így valójában kettesével csoportosítja a tálcán levő kupakokat, és annyi kupakot rak át a következő tálcára, ahány kettes csoport a tálcán volt. Így a csoportosítással, beváltással a kettes számrendszerbeli alakját kapjuk az eredetileg kirakott kupakok számának, az első tálca felel meg az 1-es, a második a 2-es, a harmadik a 4-es, a negyedik a 8-as helyi értéknek, és így tovább. Egy tálcán, azaz helyi értéken levő kupak az 1, a kupak hiánya a 0 számjegyet jelenti. A trükköt bemutathatjuk más számrendszerre is. A tízes számrendszeres változatnál 10 kupakot kellene egyszerre kivenni, 1-et továbbrakni és 9-t visszadobni a kosárba, ami elég sok számolást és nagy mennyiségű kupakot igényel, így esetleg feladatként lehet kitűzni a problémát.

\section{Algebra: Hány érme van a jobb kezedben?}

A trükk:

A bűvész kiszórja a pénztárcájában levő aprópénzt az asztalra. A közönség soraiból választott segítőnek az a feladata, hogy vegyen a bal kezébe valamennyit az érmék közül, a maradékot a jobb kezébe, majd szorozza meg 4-gyel a bal kezében levő érmék számát, és 5-tel a jobb kezében levőkét, végül adja össze a két szorzatot. A bűvész az összegből kitalálja, hogy hány érme van a jobb kezében és hány a balban.

A titok:

$A$ bủvész tudja, hogy hány érme volt eredetileg a pénztárcájában, így a $4 b+5 j=$ $4 \cdot(b+j)+j$ összeget és $4 \cdot(b+j)-t$ ismerve j majd $b$ is adódik. A szimbolikus magyarázat jól alkalmazható 7. osztályban az algebrai kifejezések tanításakor. Azonban akár alsó tagozatosoknak is megmagyarázható a trükk, hiszen már 2. osztályban a szorzásnál tanulják a gyerekek, hogy egy szám ötszöröse a számmal nagyobb a négyszeresénél, így a kapott összeg az összes érme számának 4-szeresének és a jobb kézben levő érmék számának összege.

\section{Térszemlélet: Súgnak a kockák}

A trükk:

A közönség soraiból választott segítő feldob három szabályos dobókockát, és összeadja a dobott számokat. Ezután kiválasztja az egyik kockát, és ennek az alsó lapján levő számot is hozzáadja a korábbi összeghez. Ezzel a kockával még egyszer dob, és az újonnan dobott számot is hozzáadja az összeghez. A bűvész ekkor megfordul, kézbe veszi a kockákat, megrázogatja, és a kockák megsúgják neki a kapott összeget.

A titok:

A bủvész látja, hogy az utolsó dobás után milyen számok állnak a kockák felső lapján. Ezek összegén kívül a kapott összegben még a kiválasztott kockával történt első dobás utáni felső és alsó lapon álló számok összege szerepel. Mivel egy szabályos dobókocka szemközti lapjain levő számok összege 7, így a látott összeghez 7-et adva a bűvész megkapja a végső összeget. Ezzel a trükkel a gyerekek maguk fedezik fel, tudatosítják, hogy a szabályos dobókocka szemközti lapjain álló számok összege 7. 


\section{Probléma-megoldási stratégiák: David Copperfield kártyatrükkje}

A trükk:

A közönség tagjai kiraknak 9 kártyát 3x3-as négyzet alakban. Ezeken a kártyákon kell lépkedni. A középső kártyáról indulva lépnek szomszédos kártyára lefelé, felfelé, balra vagy jobbra tetszőleges irányba haladva annyit, amennyit a büvész mond. Egy ilyen lépéssor után a bűvész megmondja, hogy melyik kártyát vegyék el. Átlósan lépni vagy üres helyet átugrani nem szabad, de visszafele lehet lépni. A büvész megint megmondja, hogy hányat lépjenek, illetve hogy a lépéssor után melyik kártyát vegyék

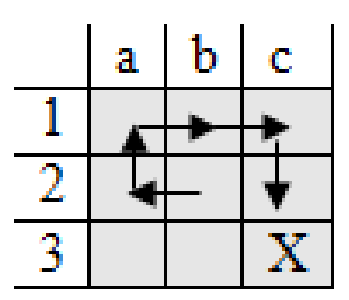

el, és így tovább:

Tedd az ujjad a középső kártyára!

Lépj 5-öt és vedd el a c3 kártyát!

Az ábra egy lehetséges útvonalat mutat. A következő lépéssor onnan indul, ahova az előzőben érkeztek.

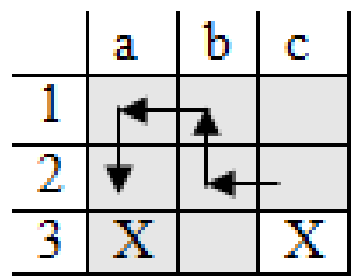

Lépj 4-et, és vedd el az a3 kártyát!

Hasonlóképpen kell lelépni a következő lépéssorokat:

Lépj 3-at, és vedd el az c2 kártyát!

Lépj 4-et, és vedd el a b3 kártyát!

Lépj 5-öt, és vedd el a c1 kártyát!

Lépj 4-et, és vedd el az a1 kártyát!

Lépj 3-at, és vedd el az a2 kártyát!

A csoda az, hogy bármerre is lépkedtek a közönség tagjai, senki sem áll azon a kártyán, amelyet a bűvész elvesz. Így végül a „gondolatátvitel” eredményeként min-

\begin{tabular}{l|l|l|l|} 
& $\mathrm{a}$ & $\mathrm{b}$ & $\mathrm{c}$ \\
\hline 1 & & & \\
\hline 2 & & & \\
\hline 3 & & & \\
\hline
\end{tabular}
denki ugyanazon a kártyán fog állni.

A titok:

Képzeljük el, hogy sakktáblaszerüen két színnel színezzük a kártyákat, így láthatjuk, hogy páros számú lépéssel mindig ugyanolyan színü kártyára lépünk, mint ahonnan indultunk, páratlan számú lépéssel pedig ellentétes színüre. Ez alapján a bűvész tudja, hogy ha a középső kártyáról indul a közönség, akkor az egyes lépések után milyen színű kártyán fognak állni, és ellentétes színű kártyát vesz el. Végül kénytelen mindenki a középső kártyára lépni. A trükk segít felfedezni a színezés és a paritás alkalmazásának stratégiáját, ugyanis a gyerekek rájönnek, hogy a kártyák kétfélék lehetnek, és mindenki ugyanarra a fajtára lép, a bủvész pedig a másik fajtából bármelyiket elveheti. Ezek a problémamegoldási stratégiák sok feladat megoldásánál hasznosak.

A trükk még hatásosabb, ha a közönség monitoron tudja követni az ujjával a lépéseit, és a „gondolatátvitel” következtében mindenki ugyanarra a kártyára fog mutatni.

\section{Összegzés}

A bemutatott büvésztrükkök akár alsó tagozatos gyerekeknek is előadhatók megadva a lehetőséget a gyerekeknek, hogy maguk jönnek rá a titokra. Reméljük ezzel a néhány példával sikerült kedvet csinálni további mutatványok kereséséhez, alkalmazásához. 
Pintér Klára

\section{Irodalom}

Gardner, Martin (1956): Mathematics Magic and Mystery, Dover Publications, Inc., New York. Naughton, Andy: Mindreader: <br>www. flashlightcreative.net/swf/mindreader/

Vann, Valerie Vann: Origami magic rose cube, $<$ br>www.youtube.com/watch?v=A8EyLFWXV_0 urbanlegends.about.com/library/bl_card_trick1.htm 